\title{
Futebol, imagens e profissionalização: a bola rola nos sonhos dos adolescentes
}

\author{
José Luiz dos Anjos" \\ Juliana Guimaraes Saneto** \\ Andreia Anchieta Oliveira***
}

\begin{abstract}
Resumo: O estudo tem por objetivo analisar os elementos sociais na construção de vivências, vínculos sociais e necessidade de pertencimento que levam adolescentes praticantes de futebol a buscar a profissionalização nesse esporte. Utiliza entrevista aberta, colhendo depoimentos de nove adolescentes de 13 a 16 anos em duas equipes de futebol, nos municípios de Vitória e Cariacica. As reduções das entrevistas basearam-se na análise discursiva de Maingueneau (1998) e a discussão teórica analisou as categorias sonho e imagens em Marc Augé (1994). Conclui que a família, a mídia televisiva e os anônimos do futebol são os agentes motivadores para a continuidade do sonho dos adolescentes em se constituírem como jogadores de futebol profissional.
\end{abstract}

Palavras chave: Futebol. Atitudes. Sonhos. Imagens.

\section{INTRODUÇÃO}

O futebol no Brasil pode ser analisado sob diversos ângulos interpostos entre si. Nesse sentido, o futebol só pode ser abordado em sua complexidade, se o compreendermos como um fenômeno social e historicamente produzido. No Brasil, o futebol sofreu um processo de descolonização europeu britânico e um processo singular na produção simbólica de jogar, sustentados pelos elementos sociais e políticos da sociedade brasileira.

\footnotetext{
"Professor adjunto IV do Departamento de Desportos e do Programa de Pós-Graduação em Educação Física do Centro de Educação Física e Desportos, da Universidade Federal do Espírito Santo; coordenador do GESESC/UFES e membro pesquisador do GEPEFIC/UNICAMP. E-mail: jluanjos1@hotmail.com.

"Mestranda no Programa de Pós-Graduação em Educação Física, membro pesquisadora do GESESC/UFES e do CESPCEO/UFES, da Universidade Federal do Espírito Santo. E-mail: jsaneto@yahoo.com.br.

"’Membro pesquisadora do PROTEORIA/UFES. E-mail: andreia@gmail.com.
} 
Com o processo de globalização e o aprimoramento das tecnologias já existentes - TV por assinatura, internet -, é possível assistir aos jogos em tempo real, de qualquer parte do planeta, e "estar com o ídolo dentro de casa". A maior parte dos craques brasileiros deixa o País para jogar na Europa com o intuito de alcançar visibilidade e retorno financeiro. $\mathrm{O}$ fato de um jogador do Brasil conseguir espaço no cenário mundial motiva ainda mais os jovens brasileiros a se profissionalizarem, já que jogar na Europa se torna referência e seus históricos sociais são semelhantes aos dos jogadores que eles admiram: a realidade social faz tornar sonho jogar na Europa.

A adolescência é uma fase de intensas transformações não só físicas como também de valores e crenças que podem ter consequências na vida adulta. Assim, o futebol, como fenômeno sociocultural, possibilita a pluralidade e a diversificação de vínculos sociais (torcidas, clubes,etc) e o compartilhamento de estilos de vida. Nesta pesquisa, investigamos e problematizamos como se mostram os fenômenos discursivos que constroem necessidades de vínculos sociais, metas e objetivos e cercam os adolescentes em seus contextos políticos e sociais. Ao considerar que as categorias de idade são construções culturais e ao tratarmos de adolescentes os sujeitos deste estudo, não desconsideramos os condicionantes históricos e sociais mas discutiremos as condições políticas que estão imergidos e as aspirações e objetivos sociais promovidos pela tensão que convivem. Portanto, não vemos a adolescência como um estágio biológico e psicológico do desenvolvimento humano - pois esta visão percebe a adolescência a partir da perspectiva que menospreza a interação juvenil e a sua produção social. Preocupa-nos como são produzidos os espaços que criam práticas e promovem relações características e típicas da modernidade e das transformações operadas nesse estágio de vida. Porém, sem desconsiderar as dificuldades materiais e simbólicas por eles vividas, opto pela abordagem antropológica que implica em recusar uma determinação linear da cultura e dos seus modos de vida. Nesse sentido, discutimos a categoria adolescente não pela falta de uma realidade social, mas sim pelos seus vínculos sociais característicos da modernidade. 
Abrimos a discussão com referências que analisaram os fenômenos sociais que constroem atitudes, a busca e a continuidade da profissionalização no futebol. Isso se fez necessário para que superássemos a discussão sobre aspectos motivacionais nos esportes debatidos pela Psicologia do esporte nas últimas duas décadas, conforme Hernandez e Gomes (2002), Gill (1986), Becker e Samulsky (2002), entre outros. Superar, textualmente, não implica abandonar os conhecimentos dos fatores e processos que levam a uma ação ou a sua ineficiência em diversas situações de uma modalidade esportiva. Se os estudos dos motivos e das atitudes implicam exame das razões pelas quais se escolhe realizar algumas tarefas com maior empenho do que outras, buscando explicações nas intenções funcionais da personalidade, entendemos que os estudos antropológicos permitem discuti-los pela via das relações sociais. Pelos caminhos das Ciências Sociais, atitude é uma ação em frente a um desafio político e social permitida pelas ligações entre corpo e abstrações cognitivas incorporadas pelas imagens da modernidade que são expressas nas ações corporais, gestuais e da linguagem.

Dessa forma, fomos impelidos a buscar em Marc Augé a discussão em torno da categoria "sonho", devido ao fato de essa categoria ser largamente encontrada nas falas de atores envolvidos nesta pesquisa e também nas análises de pesquisadores, como Damo (2007), Pimenta (2008) e Rial (2008). Embora, em dados momentos, a categoria "sonho" se aproxime do imaginário social, preferimos discuti-la como uma nova categoria social, haja vista que não identificamos um tratamento acadêmico na produção da Educação Física brasileira. Cumpre esclarecer que sonho aponta para a perspectiva de uma relação entre o imaginário e o simbólico. Nesse sentido, textualmente, imaginário social possui como base os sistemas de símbolos e essa categoria é empregada/formulada como vivências, objetivos e metas individuais dos sujeitos que aparecem nesse estudo, conotando não só como o espaço de expressão das expectativas e aspirações latentes, mas também como o lugar de lutas e conflitos sociais e políticos. Por sua vez, representação social estaremos remetendo aquilo que rege os sujeitos sociais, sem que eles percebam, atuando sempre no âmbito do coletivo. 


\section{As IMAGENS E A CONSTRUÇÃO DE VíNCULOS SOCIASS}

Daolio (1997), no intuito de discutir, pelo viés antropológico, as contradições do futebol brasileiro, procurou entendê-lo como expressão social e suas relações e interpretações na sociedade brasileira. Há 50 ou 60 anos, o rádio era o meio mais rápido de divulgação do futebol. Não havia uma identificação de uma imagem pronta, finalizada, contudo havia sempre imagens em construção pelo radio-ouvinte. Atualmente, o esporte e seus atores constituem as primeiras filas do mundo da cultura visual em que a penetração social das imagens é direta e não permanece no campo das idealizações e das construções inacabadas.

Essa produção de imagens criadas pelo mundo dos softwares modernos é recente. Há não mais de 40 anos, somente o rádio desempenhava o papel de aproximar o público do espetáculo. Da audição à visão, efeitos descrevem e constroem as imagens com seus sofisticados softwares visuais, criando e recriando impactos na percepção do mundo do espetáculo esportivo. Assim, constrói-se uma cultura de imagens formada de ininterruptas seduções, pois transforma tudo que é possível em imagens que alavancam a libido do espectador, produzindo verdadeiros sistemas de signos e não somente uma acumulação de símbolos, pois carrega significados que se locomovem além de uma duplicidade do objeto que está distante. Não se trata apenas de uma reprodução analógica que se pode interpretar na TV. É, acima de tudo, uma (re)presentação, pois lentamente a imagem se forma no próprio indivíduo ${ }^{1}$.

Para Maffesoli (1999), o mundo imaginal na sociedade moderna, isto é, a instância intermediária entre os mundos material/ objetivo e subjetivo, permite condição necessária para integrar as realidades sociais. $\mathrm{O}$ mundo material não permanece na sua origem.

\footnotetext{
'Signos são elementos representativos. Pelos estímulos e saberes que nos chegam via percepção, passamos a conhecer, relacionar e interpretar os objetos por meio da memória e das associações cognitivas. Símbolo não apresenta uma relação direta com o seu objeto, ou seja, com a coisa representada. Símbolos são figuras, objetos, gestos, quando remetem a uma ideia ou a uma significação que não tem, necessariamente, qualquer semelhança objetiva com o aquilo que simbolizam.
} 
Diríamos: ele transcende, é contínuo, ordena as imagens, promove as experiências e constrói a vida social de determinados grupos. Eis o que propomos discutir a seguir, quando das falas dos nossos informantes. Nesse oceano de imagens, os grupos os quais elas atingem passam por transformações, pela exposição incessante a um número incalculável de imagens que criam, recriam e constroem novos vínculos sociais no indivíduo moderno (AUGÉ, 1994).

O mundo de imagens também é responsável por criar ídolos. Dessa forma, os adolescentes, por meio dos veículos de comunicação, têm acesso instantâneo a tudo que acontece, particularmente, o que abrange o mundo esportivo. Assim, é comum jogadores que residem na Europa serem citados pelos jovens brasileiros. Esses jogadores servem de motivação para que os adolescentes continuem a buscar o futebol como profissão. Nesse sentido, a referência funciona como modelo amplo de novas atitudes, comportamentos e vínculos sociais, tendo a imagem como produto que necessita ser consumido.

\section{ONDE OS SONHOS SE ENCONTRAM}

Delimitando o campo de busca de informações, o cenário focalizou dois clubes de prática de futebol: o Caxias Esporte Clube, localizado próximo às comunidades de trabalhadores no município de Vitória; e o Desportiva Capixaba S.A., clube que mantém uma equipe profissional de futebol, tendo disputado o último Campeonato Brasileiro da Série A em 1993. As equipes aqui retratadas não se encontram no destaque do cenário futebolístico brasileiro, mas isso mostra que o "sonho" e os fatores que motivam e que promovem a sonhada profissão de jogador de futebol não dependem do contexto geográfico em que o garoto se encontra. A geografia não atua como fator determinante para esse projeto de vida, tanto para o garoto das regiões cosmopolitas (Rio de Janeiro, São Paulo, Porto Alegre e Belo Horizonte) como para aquele que joga descalço no campinho da várzea. Todos eles são protagonistas nas microrrelações desse espaço. 
Nove adolescentes fizeram parte da amostra com idade entre 13 e 16 anos e se assemelham em suas origens sociais, pois pertencem aos estratos operários e moram distante dos centros de treinamento. Dois desses adolescentes estão na sexta série; quatro cursam a sétima série e três estão na oitava série do ensino fundamental em instituições públicas. Somente um estuda em uma escola privada. Todos estão há mais de um ano treinando nas equipes infantis e juvenis dos clubes e todas as entrevistas foram realizadas após os treinos, individualmente, sem interferência de dirigentes ou técnicos. A escolha foi aleatória, permitindo que os adolescentes pudessem recusar as entrevistas, o que não ocorreu. Elas foram realizadas no período de outubro a novembro de 2010. Dentre os adolescentes entrevistados, o início de aprendizagem ocorreu entre os oito e dez anos de idade e dois deles já treinaram por seis meses em equipes infantis de Minas Gerais, em clubes profissionais (A4) e (A2).

Para análise e identificação dos entrevistados, utilizaremos as referências A1, A2... a A9. Algumas respostas se assemelham, mas a transcrição aborda somente uma fala dos entrevistados, contudo indicaremos os contextos semelhantes. É possível, na redução, identificar a denotação nas narrativas: posição social, política e ideológica do locutor.

Utilizamos a Análise do Discurso (AD), conforme Maingueneau (1998), pois a AD é um método cujo objetivo é não somente compreender uma mensagem, mas reconhecer qual é o seu sentido em um determinado contexto social, político e ideológico. Analisar as falas/narrativas de grupos sociais possibilita ao pesquisador conhecer a realidade social, contudo a fala deve ser problematizada, pois os sujeitos revelam a interpretação da realidade, não constituindo, portanto, na verdade em absoluto, mas em uma visão relacionada com a posição política e ideológica de quem narra, pois quem relata escolhe o que deve ou não ser lembrado. Assim, as falas são de origens subjetivas, traduzindo uma construção ideológica da realidade. Sabendo que o discurso é uma prática, ou seja, uma ação do sujeito 
sobre o mundo, portanto as narrativas devem ser contextualizadas como um acontecimento/ação pois, na fala, funda-se uma interpretação social e constrói-se uma vontade tida como verdadeira. Ao enunciar um discurso, há uma ação sobre o mundo, marcando posições políticas e ideológicas, selecionando sentidos e o que deve ou não deve ser enunciado.

Assim, vemos necessidade de nos dirigir pela denotação ${ }^{2}$, ou seja, a ação discursiva que aponta a posição política e ideológica nas narrativas dos adolescentes. $\mathrm{Na}$ análise, lançamos a seguinte questão: quais as condições de produção do discurso a ser analisado? (as representações que interferem na sua construção e a conjuntura política existentes nas relações de construção de representações); e, em um segundo momento, questionamos: quem produziu o discurso? Nesse caso, deve-se atentar para a inserção social e política do sujeito que está elaborando o discurso assim como para as intenções e os resultados visados, levando em conta o campo ideológico em que o sujeito do discurso se estabelece.

\section{DiSCURSOS DOS ADOLESCENTES: SONHOS, REALIDADES E IMAGENS}

Abordando sociologicamente a família, a casa, a origem familiar onde se vislumbram os cenários primevos dos adolescentes, podemos observar que são oriundos dos estratos sociais de operários que, embora tenham distinções profissionais, se assemelham na baixa qualificação para o trabalho e não estão integrados ao poder de consumo moderno. As famílias não são numerosas, formadas, em média, por quatro pessoas. Os pais possuem nível de instrução do ensino fundamental e ocupam, no mercado de trabalho, os afazeres menos remunerados:

\footnotetext{
${ }^{2}$ Denotação é o sentido que as palavras assumem no contexto da narração. A relação existente entre o sentido da expressão e a intenção da ação discursiva configura a denotação. Significado denotativo é o conceito que remete a um certo significado dado pelo narrador presente em categorias, palavras e conceitos.
} 
O meu padrasto é vigilante e minha mãe trabalha de ganho por dia, e tenho um irmão que trabalha na Guarda Municipal e outro no porto. (A4); Meu pai não chegou estudar e minha mãe possui a quinta série incompleta e em casa somos em cinco... só eu não trabalho. Sou o mais novo (A6); e Meu pai é pedreiro e a minha mãe trabalha na Serv-Limp... Sou o mais velho de casa e minha irmã vai pra escolinha (A8).

Observando a estratificação social no Brasil, para os jovens de famílias operárias, existem poucos exemplos de atores advindos das camadas das classes sociais populares que conseguiram ser bemsucedidos em suas escolhas profissionais, privilegiando os estudos. Assim, como exemplo para esses adolescentes, resta ver, nas figuras dos jogadores de sucesso, um alento para sair da baixa situação social. A redenção social da família se encontra na consecução do alcance dos objetivos dos adolescentes, pois a leitura da realidade aponta as condições e possibilidades factíveis de se alcançar a ascensão social pela via do futebol:"Quero ser jogador de futebol pra mudar minha vida e da minha família. Meu pai garante eu ficar sem trabalhar, porque ele acredita que, se der certo, vai compensar" (A4, acompanhado por A2, A9, A6 e A5) consubstanciado por esta fala de A3: "Não me preocupo com material, chuteira... o Fio [treinador de futebol da comunidade onde reside] me dá um par todo ano. Ele disse que está apostando em mim". Essa fala faz com que a família, por meio de elogios dos pais, dos tios e dos agentes anônimos (voluntários que atuam nas comunidades), renove as forças do iniciante a ser jogador de futebol. Trata-se, portanto, de um projeto familiar coletivo e de ascensão social, no qual o adolescente entende ser o "escolhido" para tentar postular o status simbólico da profissão (RIAL, 2008) e fazer o caminho inverso dos demais em busca do sucesso profissional.

Nessa busca profissional, a construção de objetivos e alcance de metas que sustentam o "sonho" de se constituir jogador profissional parte de diversos agentes familiares, como observamos: "Olha... quem me anima? Eu sou o mais novo... homem... não preciso trabalhar em casa e meu tio mais novo... todos eles... meu pai, tudo" 
(A4). Pimenta (2008, p. 124) encontrou essas mesmas palavras quando analisou o sonho de ser jogador de futebol de seus entrevistados e observou esse processo de reciprocidade:

[...] na comemoração dos gols, nas entrevistas e nas manifestações públicas é comum ver um jogador mandando beijos, abraços, lembranças, felicitações ou agradecimentos à família. Em alguns casos, podese imaginar o quanto de sacrifício a família fez (ou faz) para sustentar o sonho do filho.

A sustentação do sonho pela família também é concedida quanto ao tempo para jogar futebol. O início da prática desse esporte aponta sempre um local próximo da residência do jovem e na própria comunidade. Todos iniciaram sua prática/treinamento em centros de formação desportiva nos bairros onde residem, ou em locais desprovidos de infraestrutura oficial. Essa cultura do futebol de que tratamos tem dois pontos importantes: o ato de aprender a jogar futebol, onde e como e, num segundo momento, os anônimos que sustentam essa continuidade motivando garotos e adolescentes a alimentar o imaginário de algum dia se constituírem profissionais da bola.

O início da prática desses adolescentes foi nos times da comunidade que jogam nas "várzeas", nos campos das escolinhas das prefeituras ou brincam de bola "nas ruas estreitas dos bairros". Esses locais, segundo Silva Neto (2000) e Santos (2000), foram, e ainda constituem, locus de onde saem muitos profissionais que são observados por olheiros locais. Além de constituir um local para que olheiros possam indicar futuros jogadores para as equipes de base de clubes de futebol profissional, essa prática permite aos adolescentes conhecerem possibilidades de jogar em outras equipes constituídas e estabelecer um padrão de jogo, de futebol, admirados, tradicionalmente, pela crítica jornalística do futebol. Trata-se do futebol-arte, o futebol malandro, que tradicionalmente se ventila em uníssono que somente o brasileiro tem. Quando perguntamos onde aprendeu a jogar, a dar dribles e fintas, ouvimos, praticamente, de todos os adolescentes, consubstanciados no entrevistado (A4): "Ah! eu sempre assistia televisão, os caras jogando bola aí eu se animei 
pra jogar, sem ninguém pra ensinar" (A3, A5, A6, A7 e A9). Essa fala é enfatizada pela crítica que afirma que a liberdade e a criatividade se encontram nos campinhos das várzeas, longe de técnicos que prendem o corpo do jogador, conforme encontramos em Soares (1995) e Florenzano (1999), que atribuem esse fato à capacidade dos jogadores de representar - algumas expressões do jogo de futebol se explicam pelo espaço de aprendizagem e pela intimidade com a vida social.

A rua e o campinho de futebol, na comunidade, constituem locus de perpetuação de uma cultura permeada pela paixão, sonhos sociais infantis e juvenis de um dia pertencer a uma equipe de base de um clube de futebol profissional. Também constituem o espaço de construção de uma singularidade de jogar futebol, singularidade esta tão discutida por Soares (1995). Para consubstanciar essa análise, a fala de um dos atores (A5) revela: "Cheguei até o Caxias por indicação do goleiro... eu vim fazer teste, aí eu vim, aí eles disseram pra eu ficar... o técnico falou que tenho um futebol malandro, bonito [...]", assim como A9:

[...] o professor da escolinha da prefeitura falou que, se eu quisesse ter futuro que procurasse um time profissional, mas eu não conhecia ninguém, até que o Buru [jogador de futebol de areia da Seleção do ES] me falou pra vir. Eu vim junto com mais três colegas... eles vieram com o Diguinho lá de Cariacica.

Acompanhando a iniciação no futebol, nota-se que a maioria dos adolescentes prefere as posições de linha de frente, ou seja, atacante. Os adolescentes/atores revelam inclinação para posições diversas, contudo o imaginário está todo voltado para as posições de destaque, conforme se manifesta A9:

$\mathrm{Eu}$ joguei como lateral, na escolinha do meu tio, depois fui pra meia e agora, no Caxias, tô como atacante. [...] isso depende... quando faz teste, atacante não passa bola pra atacante [...] daí você tem que buscar bola no meio, daí o técnico chega e fala: 'Você serve pra jogar no meio', e você acaba mudando $[. .$.$] mas eu sou da frente.$ 
Ou seja, querem atuar no ataque, já que os jogadores de maior destaque e reconhecimento no futebol brasileiro, historicamente, jogam nessas posições que são mais privilegiadas, mas, contemporaneamente, encontramos destaques em outras posições. Para Rial (2008, p. 31),

[...] os futebolistas brasileiros não apenas estão numericamente presentes mas, mais importante, têm uma presença qualitativamente central pois não raramente ocupam as posições principais em cada equipe, são os destaques, seja atuando no ataque, posição que historicamente tem prevalecido como lócus de reconhecimento dos principais jogadores seja atuando na defesa, o que é uma novidade dos últimos anos pois raramente eram defensores os principais jogadores de uma equipe.

Portanto, jogar no ataque, "ter um futebol bonito", com efeito, são qualidades responsáveis por colocá-lo em um espaço objetivamente classificável e apontam a valorização no mundo do futebol global. Trata-se de uma produção simbólica funcionando como uma força instituidora de competências necessárias aos debutantes para atuar no futebol - portanto, jogar "bonito", no Brasil, corresponde a ser herdeiro de um elevado capital cultural e, no mercado futebolístico, detentor de moeda de troca no mercado do futebol. Jogar bem, ou ser avalizado por um star do futebol, significa, no mercado do futebol-espetáculo, que o "capital corporal" expresso pela ginga, pela malandragem é generoso com os privilegiados que detêm esse status corporal (RIAL, 2008).

Parece-nos que ser atacante é uma questão de distinção, distinção social para os nossos atores, preenchimento de status que se identifica pela simbologia do herói, do ídolo, figura imanente ao esporte, que se traduz pelos grandes nomes do futebol. Até hoje, no Brasil, a história do futebol e seus heróis tem sido contada pelos gols, dribles, passes certeiros, estilos de chutes e fintas dos atacantes, sem, contudo, desprezar as atuações e lideranças de zagueiros e defesas de goleiros. Cria-se um mito, que é instituído pela mídia mediadora como instituição e pela modernidade construtora das dimensões simbólicas. 
Há, então, uma relação direta entre o iniciante (nossos atores) e os heróis, pois ser atacante é sinônimo de prestígio pela imprensa e, dificilmente, ele será culpado pela derrota do time. Esse discurso pode ser visto nas falas de nossos atores, visto que, entre posições e outros fetiches que adentram o imaginário desses atores, aparecem outros elementos que povoam esse imaginário social. As diversidades desses elementos se traduzem palpáveis em camisetas, botons, flâmulas, fotografias, álbuns, toalhas, pôsteres, que se multiplicam como expressão de uma cultura que procura construir identidades ${ }^{3}$ permeadas pelos meios midiáticos.

O sonho, na modernidade, segundo Augé (1998) é uma resposta à angústia existencial em frente às experiências sociais negativas da passagem do tempo. O sonho, que aqui tratamos, é a capacidade mesma de fundar o real e percebê-lo, pois as imagens são as únicas passagens/caminhos a que se pode recorrer e que são imediatamente visíveis e interpretáveis. Com efeito, à luz das interpretações antropológicas, sobretudo, trata-se de uma espaço construído, porque seus membros nunca conhecerão todos os demais; na mente de cada ator, reside uma imagem da comunidade da qual ele participa. Ou seja, ainda que os limites dos espaços "sonhados" do futebol não existam, seus atores são capazes de criar e imaginar tais fronteiras e se expressar como se estivessem em seu interior, pois criam e recriam relações/produções sociais superficiais com seus membros.

Augé (1994), em Sentido dos outros, trata da representação. Para esse antropólogo francês, os símbolos (ser atacante ou ter camisetas) são representações coletivas, temporariamente imutáveis,

\footnotetext{
${ }^{3}$ Para Marc Augé (1994), é preciso pensar a cultura, a identidade, sempre em movimento, nunca de maneira fixa. Seu objeto converge para o que autor chama de antropologia do próximo em "Não-lugares: introdução a uma antropologia da supermodernidade". Augé (1994) define os chamados não-lugares como um espaço de passagem incapaz de dar forma a qualquer tipo de identidade. Discute a capacidade de a antropologia analisar e compreender a sociedade de hoje, caracterizada por ele como supermodernidade, e apresenta as seguintes características: a) um novo entendimento da categoria de tempo (hoje, o ontem já é História, tudo se torna acontecimento e, por haver tantos fatos, já nada é acontecimento. Logo, organizar o mundo a partir da categoria tempo já não mais faz sentido); b) as constantes transformações espaciais, a mobilidade social e o enorme fluxo de informação indicam o que o mundo encolheu. Esses fatores enfraquecem as referências coletivas, gerando um individualismo exacerbado, porém sem identidade. Portanto, o chamado não-lugar caracteriza-se por não ser relacional, identitário e histórico.
} 
que assim se figuram no tempo e no espaço da fase da adolescência. Nesse caso, vive-se uma realidade contínua, pois não mudam as condições de simbolização.

Vive-se o paradoxo, pois temos a sensação de que conhecemos tudo e estamos dentro da realidade construída socialmente. Percebemos essa realidade na argumentação de um ator. Revela conhecer "O Denilson, que já jogou no Real Betis. Ele já esteve aqui várias vezes" (A9), referindo-se a visitas que o ex-profissional fez à escolinha particular onde jogava e acrescenta "Faço parte do Orkut dele". Esse último argumento é acompanhado por mais cinco adolescentes (A1, A3, A5, A6, A7), colocando-os como personagem do mundo dos "sonhos" no interior da própria realidade. A proximidade das relações promovidas pela cultura visual e pela tecnologização da modernidade encena e constrói relações superficiais e também cria falsas fronteiras de pertencimento. Ser adicionado ao Orkut de um ídolo do futebol traduz esse "mundo de pertencimento".

Para Augé (1994), no mundo dos sonhos, existem diferentes estágios: há o mundo da revelação das coisas e o mundo da ausência das coisas reais. Tais estágios/mundos são revelados na fala de um dos atores (A4): "Porque sou da mesma família e a mesma oportunidade que ele teve eu também posso [...]" e A8 complementa: "Nós todos aqui não tem muita diferença desses jogadores que estão jogando no Fla, Vasco ou no Bota". Essa fala revela a falta de identificação um mundo real, ou seja, o mundo de oportunidades sociais e políticas. Ora, essa ausência das coisas reais é justamente o mundo de nossos atores, pois as ausências das coisas sociais/ políticas permitem construir um mundo de coisas não reais, vendo no outro ou nos fetiches do mundo esportivo o alcance da realidade construída pelo poder das apropriações do mundo das ausências de coisas reais.

Nesse mundo de ausências de coisas reais, o estudo e a escola são vistos como algo funcional nas ausências de coisas sociais, pois, "[...] se for jogar em times de fora, jogar na Espanha e não souber falar espanhol, tem que estudar" (A1), conforme revela um de nossos atores, acompanhado por outros discursos. Quando perguntado 
acerca de estudos, ele nos responde: "Tem que ter pra ser profissional, tem que assinar a ficha, saber o que o cara tá falando" (A1). Outro ator diz: "Tem vez que tem campeonato e, se não tiver nota boa, não viaja" (A3). A motivação de estudar é parte de um princípio de alcançar os objetivos "sonhados". Essa realidade marca os adolescentes que buscam o futebol como profissão, pois adiam o desenvolvimento acadêmico em função de um sonho da profissionalização.

Buscamos conhecer esse "sonho" de que falamos nos discursos de nossos informantes e assim foi possível desvelar essa categoria. O sonho parece ser um objeto manipulável, criado pelos próprios sujeitos. Trata-se de um objeto distinto, na visão de Augé (1994, p. 79), bem diferente daquilo que se percebe: "[...] que ele não tem nem cor nem os brilhos que os olhos vêem". Se não há outros caminhos, não há como ter outras escolhas, já que os sonhos são criação da representação social.

Percebe-se que o sentido da palavra "sonho", discursado pelos atores, faz referência a algo que vai se completar, que pode ser determinado. Os pensamentos por si sós se esgotam e finalizam no alcance de um determinado objetivo. Esse parece ser o caminho a ser percorrido para o alcance dos objetivos. Nesse sentido, o significado de sonhar em querer ser jogador de futebol só existe para o sujeito que sonha, como nos ilustra o argumento de A3: "Meu maior [sonho] como adolescente... não sei dizer, sei que tenho esse sonho de ser jogador de futebol desde criança, desde pequeno... meu maior sonho é dar o toque na bola no começo do jogo [...]". Indicando uma atitude discursiva, A8 complementa: "[...] quando a bola rola no começo do jogo... tá aí meu maior sonho... eu penso nisso... sei que é difícil chegar lá... até duvido... mas dar o toque na bola... ser o primeiro... é isso".

Esse fenômeno não ocorre somente no Brasil. Bourke (2003), ao analisar as opções/progressões de adolescentes irlandeses, com o objetivo de se tornarem jogadores de futebol, encontrou, como 
primeira opção, "jogar em um time londrino". Para a autora, a "invasão" do futebol londrino e o status de jogar no Reino Unido constitui uma das principais mobilidades de opções dos adolescentes irlandeses.

A representação construída tradicionalmente tem seus símbolos que dão lugar às palavras. Símbolos esses que se constituem em linguagem; são as imagens arquitetadas que modulam posições e conferem sentido aos possíveis vínculos sociais. A próxima fala exemplifica isso: "Lá em casa tem foto do Sávio, do time do Flamengo, do Zico... A do Zico está autografada. Essa é do meu tio que o conheceu... tá lá no quarto" (A5). Tal fala revela uma forma simbólica de subjetividades que se constitui como ordem mediadora necessária para a pulsão de continuar sonhando.

Para Augé (1994), a modernidade destrói o imaginário e se aproxima da ficção, não havendo uma separação entre o imaginário do sujeito e a ficção, pois o imaginário, aqui, é a própria ficção. Nesse sentido, ocorre a impotência da construção de uma representação pelo sujeito: "Eu vejo pela TV que eles jogaram muito, foi muita luta pra eles chegarem até lá" (A9). Isso significa dizer que as condições para que essa relação seja questionada não acontecem, pois a imagem mostrada é a própria ficção. Ora, a existência de uma realidade só é possível no momento em que ela permite compreender o mundo por meio de um olhar diferenciado, pressupondo o diferente a partir do indivíduo e por meio de experiências dos contatos sociais. Daí a realidade ser relacional.

No mundo de ficção, as relações são singulares, ou seja, são individuais. O indivíduo/ator, ao se ver no outro e com o outro, destrói a possibilidade de alteridade, pois o eixo da alteridade que liga categorias que promovem a identidade é atravessado por uma força que não permite tal distinção, porque o indivíduo se situa no campo/ mundo ficcional. Não havendo essa relação com o outro, tais identidades não são elaboradas, pois o mundo vivido não é ritualizado e não há dinâmica de vida com o outro e com o coletivo, para entendêlo como diferente e daí brotar, minimamente, a possibilidade de identificar-se com o diferente e promover uma possível ruptura com as "forças" que o colocam nesse mundo de "sonhos". 
Augé (1994) nos leva a pensar no lugar como espaço antropológico, como um espaço identitário, relacional e histórico. Esse espaço ficcional constitui o não-lugar, aqui denominado de espaço e mundo dos "sonhos" dos atores. Esse será um lugar não relacional, não identitário e não histórico. Assim, não são somente aeroportos e estações ferroviárias que constituem um não lugar, como Augé (1994) teoriza. Ampliamos a interpretação de que o espaço do mundo ficcional do futebol, criado e constituído pelos meios midiáticos modernos, é a-histórico, visto que cada indivíduo traça individualmente sua trajetória, não havendo uma construção coletiva de identidade que ocupe os espaços transitórios do futebol.

Dessa forma, cria-se uma verdade fictícia entre o espectador e a tela da TV, porque as imagens veiculadas difundem uma ilusão diretamente proporcional à realidade que elas registram, resultando em discursos, como o que se segue, promovido por A9: "[...] todo garoto que joga tem o sonho de ir pra Europa, pra poder chegar à Seleção. Veja a nossa Seleção... pra você chegar lá tem que ter jogado na Europa, não tem ninguém que só ficou aqui", discurso acompanhado por (A2, A6 e A7).

Isso é o que Augé (1994) chama de estado de passividade, em que os espectadores absorvem tudo pelos olhos, facilitando a identificação com o processo de projeção das imagens. O importante para que isso se concretize é a própria imagem como discurso, como instância que evoca a realidade.

Essa realidade criada é arquitetada nos espaços mínimos de recortes de imagens da TV produzidas pelos web designs televisivos, avaliadas pelos apresentadores dos programas Troca de Passes, Globo Esporte, Jogo Aberto, entre outros, percebidas nas concretizações das linguagens expressas nas falas dos entrevistados, constituídas de profissionais bem-sucedidos. A realidade que tratamos não tem fronteiras de mercado, como se pode observar nos depoimentos a seguir: "Se você for um bom jogador, tendo um bom empresário que é muito importante, eu acho que dá futuro, você pode se vê dentro do futebol" (A4); "Não é só jogar bem, tem que ter um bom empresário e ainda a TV tem que dar uma vez pra você 
mostrar seu futebol, ficando aqui [refere-se ao Espírito Santo], vai ser muito difícil... a nossa rodada não aparece na TV" (A2). Ter empresário e se relacionar bem com a imprensa oferecem um campo próprio de relações que estabelece limites fronteiriços de análise. Kruschewsky e Morel (2005) tecem discussões acerca da promoção de jogadores de futebol. Para os autores, a promoção de jogadores individualmente é bem maior que a da própria equipe. No caso de o iniciante encontrar um "mentor" para inserir o adolescente numa equipe que o promova, trata-se, antes de tudo, e aqui falando a linguagem do futebol, de encontrar um "bom corretor". Nota-se que os dois adolescentes, A2 e A4, denotaram essa posição política, pois ambos já tiveram experiência de serem indicados para equipes infantis de clubes profissionais.

Os acontecimentos e fatores existentes no mundo profissional do futebol são convenções sociais/políticas; são transmitidos e aceitos sem que possam ser analisados pelos indivíduos que se encontram nesse espaço e, mesmo que exista uma necessidade, esta se encontra ausente de sua consciência. Para efeito de análise, essas convenções surgem no cotidiano, trazendo a sensação de que as escolhemos, quando, na verdade, os indivíduos estão envolvidos num processo mediante o qual eles fazem opção, mas não decidem.

Com efeito, os programas televisivos, em suas projeções de imagens e linguagens, criam espaços onde somente os agentes nele existentes podem transitar (jogadores iniciantes ou profissionais que debutam espaços, empresários, imprensa). De modo algum, os sujeitos representados nesse espaço estão num campo de passividade e neutralidade, pois cada qual imagina estar dentro de um determinado limite: "O que mais gosto de ver na TV... é o GB falando com um jogador, mostrando a casa dele, falando do empresário dele" (A2). Essa fala o leva a pensar que isso não é determinista, mas trata-se de uma rede complexa de "interações sociais superficiais" e, atualmente, a fronteira entre o real e o ficcional não é nítida, ainda que num lugar ou num não lugar ela exista. 
Há uma institucionalização de bens simbólicos difundidos em relações que perpassam o "terreno social". Os atores que assim entendem ter um capital de produção - o futebol - consideram que a profissionalização se dá em continuum crescimento, diferentemente das outras relações existentes no mercado de trabalho.

Ainda com Augé (1994), penetramos no mundo da ficção que é superior às imagens produzidas pela mídia. É oportuna essa discussão, pois a sensação de sermos um cidadão do mundo está presente. Augé (1994) discute a representação social, coletiva e a ficção, conceituando o atual momento de supermodernidade que destrói a relação existente entre os imaginários e a ficção. Nesse sentido, a relação global dos indivíduos com a realidade/real se transforma/modifica mediante o efeito das representações associadas ao desenvolvimento tecnológico e à aceleração/movimento da história.

Assim, entendendo que toda sociedade viveu e se organizou pelos símbolos, esses se tornaram representações coletivas. Quando mudam as condições de simbolização promovidas pela destruição do real pela aceleração da supermodernidade, os indivíduos têm a sensação de que conhecem tudo, enfim, são oniscientes. As identidades se perdem, a cultura se dissolve e os indivíduos vivem na superficialidade das relações (AUGÉ, 1994). Isso é que possibilita a identificação do sonho em que tudo se mescla e se confunde e todas as imagens se somam às encenações dos próprios atores (dos adolescentes). Constroem-se, assim, espaços não demarcados. Não há separação entre o real e o ficcional, e os informantes revelam isso em seus discursos. Por exemplo: "Ah! Eu já conversei com o Denilson, com o Sávio" (A3, A8). Julgam que o fato de conhecer a vida privada do ídolo os torna pertencentes a um espaço demarcado por um não lugar, a-histórico, não relacional e sem identidade. É das encenações dos fatos e das relações estabelecidas que provém a falta de símbolos criadores de vínculos, pois sonhar socialmente cria uma relação exclusiva com a imagem. É um sonhar sem identidade e absorvido pelo mundo de ausências de coisas reais e políticas. 


\section{Considerações FinaIS}

Vimos que a categoria "sonho" discutida no interior da pesquisa aponta um deslocamento no cenário da literatura da Educação Física brasileira. Entendemos que, dentre os muitos desafios lançados nas análises subjetivas no mundo contemporâneo, espera-se que novos tratamentos atribuídos às categorias analisadas pela Educação Física sejam capazes de compreender e dar nova configuração aos estudos das representações sociais, e não indicar uma simples perspectiva analítica de estudos.

Nas análises das falas/discursos, não percebemos um processo de rupturas e descontinuidades nas falas dos entrevistados, mas uma legitimação em relação a uma certa tradição, o que exige reiteradas análises nas dimensões construtivas do discurso, devido ao fator denotativo presente nas falas dos adolescentes, ou seja, a posição social, o contexto político e o campo ideológico que constroem as representações.

Com efeito, a discussão pela antropologia da mobilidade permitiu um tratamento para esses fenômenos sociais. A família, a mídia televisiva e os anônimos do futebol são os agentes que constroem objetivos, metas e possibilitam vivências para a continuidade do "sonho" dos adolescentes de se constituírem como profissionais de futebol. O mundo do futebol, dos adolescentes, encontra-se nessa "criação" da modernidade, como teoriza M. Augé (1998). Na pré e pós-abstração do mundo das imagens, percebemos que elas constroem fronteiras não demarcadas e os atores entendem que estão vivenciando um mundo desterritorializado, mas reconhecido por sua identidade por apresentar um futebol conhecido internacionalmente, o "jeito" de jogar futebol.

$\mathrm{Na}$ fala dos atores, parece que jogar na Europa é a "globalização" que condensa o semantismo das mudanças, e um dos aspectos mais significativos dessas transformações é a cultura de imagens que promove uma compressão espacial e temporal gerada pela extrema velocidade da circulação de informações (AUGÉ, 1994). Essas transformações ainda não são plenamente 
compreendidas pelos referenciais antropológicos que analisam a representação coletiva do futebol na sociedade brasileira e que percebem que o planeta diminui, o tempo se estreita e se instala um regime de ficção que influencia a vida social.

Essa questão nos abriu nova perspectiva para compreender os novos compartilhamentos, os sonhos de pertencimento e os vínculos de sociabilidade real e virtual, num mundo de imagens globalizadas que passam pela articulação das noções de "global" e de "local". É o deslocamento de bens culturais primariamente locais (futebol-arte e classe social), cruzando fronteiras e provocando percepções de que o global está muito próximo. Devido às questões sociais, o mundo é constantemente perpassado por um localismo de tradições - e tradição remete a uma identidade, a um sentimento de pertença, a uma comunidade simbólica (os jogadores que obtiveram sucesso são socialmente semelhantes aos nossos atores). Mostra-se, assim, nítida a necessidade de haver uma compreensão dos vínculos sociais que convive paralelamente num determinado espaço de construções simbólicas.

Emerge, portanto, uma questão importante a ser investigada, em outro momento, a identidade e o risco de perdê-la, pois, num mundo de informações aceleradas, o fenômeno das imagens atua como um processo de decomposição de identidades individuais - e uma equação passa a ligar indissoluvelmente o fenômeno da valorização cultural local (futebol brasileiro) e o da valorização da identidade no mundo global: a grande moeda de troca que identifica os e nos atores é possuir um capital cultural/simbólico para alcance de sua profissionalização, que pode ser negociado num mundo onde a identidade é secundária. 
Soccer, images and professionalization: soccer plays with every teenage dream

Abstract: The study aims to analyze the social elements in the construction of attitudes that lead teenagers who practice soccer to go for professionalization in such sport. It uses open interviews, collecting testimonies from nine adolescents aged 13 to 16 years old in two soccer teams in the cities of Vitória and Cariacica. The reductions of the interviews were based on the discursive analysis of Maingueneau (1998) and the theoretical discussion examined the categories dream and images in Marc Augé (1994). It concludes that the family, the television media and the soccer anonymous are the motivators for continuing the dream of teenagers to become professional soccer players.

Keywords: Soccer. Attitudes. Dream. Images.

Fútbol, imágenes y profesionalización: el balón rueda en los sueños de los adolescentes

Resumen: El estudio tiene por objetivo analizar los elementos sociales en la construcción de actitudes que llevan a los adolescentes que practican el fútbol a buscar la profesionalización en ese deporte. Utiliza entrevista abierta, recogiendo testimonios de nueve adolescentes de 13 a 16 años en dos equipos de fútbol, en los municipios de Vitória y Cariacica. Las reducciones de las entrevistas se basaron en el análisis discursivo de Maingueneau (1998) y la discusión teórica analizó las categorías sueño e imágenes en Marc Augé (1994). Concluye que la familia, los medios televisivos y los anónimos del fútbol son los agentes motivadores para la continuidad del sueño de los adolescentes en constituirse en jugadores de fútbol profesional.

Palabras clave: Fútbol. Actitudes. Sueños. Imágenes 


\section{REFERÊNCIAS}

AUGÉ, M. Não-lugares: introdução a uma antropologia da modernidade. Lisboa: Bertrand, 1994.

A guerra dos sonhos. Campinas: Papirus, 1998.

. L'autre proche. In: SEGALEN, Martine (Org.). L'autre et le semblable: regards sur l'ethnologie des societies contemporaines. Paris: Presses du CNRS, 1988. p. 19-34.

BANCHETTI, L. D. Futebol e imprensa: paixão e negócio. Revista Ponto-e-Vírgula, São Paulo, n. 6, p. 252-266, 2009. Disponível em: <www.pucsp.br/ponto-e-virgula>. Acesso em: 12 fev. 2011.

BECKER JÚNIOR, B; SAMULSKI, D. Manual de treinamento psicológico para o esporte. Novo Hamburgo: Feevale, 2002.

BOURKE, A. The dream of being a professional soccer player: insights on career development options of young. Journal of Sport \& Social Issues, v. 27, 2003. Disponível em: <http://jss.sagepub.com>. Acesso em: 12 jul. 2010.

DAMO, A. S. Do dom à profissão: formação de futebolistas no Brasil e na França. São Paulo: Aderaldo e Rothschild, 2007.

DAOLIO, J. Cultura: educação física e futebol. Campinas: Editora Unicamp, 1997.

GILL, D. L. Psychological dynamics of sports. Champign: Human Kinetics, 1986.

KRUSCHEVWSKY, A. B.; MOREL, M. A cobertura da mídia impressa da seleção brasileira de futebol ao longo das Copas do Mundo. Revista Brasileira de Ciências do Esporte, Campinas, v. 26, n. 2, p. 140-148, 2005

HERNANDEZ, J. A. E.; GOMES, M. M. Coesão Grupal, ansiedade pré-competitiva e o resultado dos jogos em equipes de futsal. Revista Brasileira de Ciências do Esporte, Campinas, v. 24, n. 1, p. 139-150, 2002.

LEWANDOWSKY, T. Lingüística: ciencia del lenguaje: estúdio del lenguaje con la finalidad de describir y explicar el lenguaje humano, sus relaciones internas, su función, su papel en la sociedad. Barcelona: Paidós, 1986.

MAFFESOLI, M. No fundo das aparências. Petrópolis: Vozes, 1999.

MAINGUENEAU, D. Termos-chave da análise do discurso. Belo Horizonte: EDUFMG, 1998.

PIMENTA, C. A. M. O sonho na juventude contemporânea: juventude e futebol. Revista Ponto e Vírgula, São Paulo, n. 3, p. 112-119, 2008. Disponível em: <www.pucsp.br/ponto-e-virgula>. Acesso em: $14 \mathrm{fev} .2011$. 
RIAL, C. Rodar: a circulação dos jogadores de futebol brasileiros no exterior. Revista Horizontes Antropológicos, Porto Alegre, v. 14, n. 30, p. 21-65, jul./ dez. 2008.

SANTOS, M. A. Periferia e várzea: um espaço de sociabilidade. In: COSTA. M. R. (Org.). Futebol: espetáculo do século. São Paulo: Musa, 2000.

SILVA NETO, E. B. O verdadeiro celeiro. In: COSTA. M. R. (Org.). Futebol: espetáculo do século. São Paulo: Musa, 2000.

Endereço para correspondência:

José Luiz dos Anjos

Rua Sete, n. 20 apto 705 - Praia de Itaparica

CEP 29105770 - VILA VELHA - ES

Recebido em: 04.04.2011

Aprovado em: 27.03.2012 
